СУТНІСТЬ I СТРУКТУРА ЕМОЦІЙНОÏ КОМПЕТЕНТНОСТІ

МАЙБУТНІХ УЧИТЕЛІВ МУЗИЧНОГО МИСТЕЦТВА

В КОНТЕКСТІ ХОРМЕЙСТЕРСЬКОЇ ПІДГОТОВКИ

\title{
CONTENT AND STRUCTURE OF THE FUTURE MUSIC TEACHERS' EMOTIONAL COMPETENCE IN THE CONTEXT OF CHOIRMASTER TRAINING
}

УДК 378.147:371.124:78

DOI https://doi.org/10.32843/2663$6085 / 2021 / 38.8$

\section{Радюшина С.А.,}

старший викладач кафедри диригентсько-хорової підготовки Південноукраїнського національного педагогічного університету імені К.Д. Ушинського

\section{Ткаченко М.ю.,}

\section{старший викладач кафедри} диригентсько-хорової підготовки Південноукраїнського національного педагогічного університету імені К.Д. Ушинського
Стаття присвячена теоретичному обгрунтуванню проблеми емоційної компетентності майбутніх учителів музичного мистецтва як важливої складової їхнього профресійного становлення. У якості мети статті визначено обгрунтування сутності, змісту і компонентної структури емоційної компетентності майбутніх учителів музичного мистецтва в контекст хормейстерської підготовки. Реалізація мети дослідження здійснюється за допомогою методів теоретичного дослідження: аналізу, синтезу, узагальнення, концептуалізації та моделювання. Компетентність розглядається як складний комплекс знань, умінь, навичок, досвіду і ставлення. Емоційна компетентність у контексті мистецько-педагогічної діяльності тлумачиться як чинник забезпечення ефрективної комунікації фрахівця, який уможливлюе здатність налагоджувати взаєморозуміння з іншими, творчо і глибоко осягати художньо-образний зміст творів мистецтва та створювати певний емоційно-інтерпретаційний зв'язок у прочесі художньо-педагогічної комунікації. Емоційна компетентність майбутніх учителів музичного мистецтва в контексті хормейстерської підготовки визначається як інтегральна якість, комплекс знань, умінь, навичок і практичного досвіду усвідомленого оперування емоційною інформацією та вольової регуляції емоційної поведінки у процесі роботи з хором. Складовими емочійної компетентності визначено такі компоненти: особистісно-пізнавальний (здатність до пізнавальної діяльності в галузі емоційної інсоормації), аналітикоінтерпретаційний (здатність до аналізу та інтерпретації емоційної інфрормації), чуттєво-експресивний (здатність створювати емоційно-резонансний музичний простір засобами диригентської експресіі) та ресрлексивно-регулятивний компонент (здатність до контролю і своєчасної регуляції емоційного резонансу).

Ключові слова: емоції, компетентність, емоційна компетентність, хормейстерська підготовка, майбутні учителі музичного мистецтва, компонентна структура емоційної компетентності.

The article is devoted to the theoretical substantiation of the future music teacher's emotional competence problem as an important component of their professional development. The purpose of the article is to substantiate the essence, content and component structure of emotional competence of future music teachers in the context of choir training. Realization of the purpose of research is carried out by means of methods of theoretical research: the analysis, synthesis, generalization, conceptualization and modeling. Competence is seen as a complex set of knowledge, skills, abilities, experience and attitude. Emotional competence in the context of artistic and pedagogical activities is interpreted as a factor in ensuring effective communication of the specialist, which enables the ability to establish mutual understanding with others, creatively and deeply comprehend the artistic and figurative content of works of art and create certain emotional and interpretive connections in artistic and pedagogical communication. Emotional competence of future music teachers in the context of choir training is defined as an integral quality, a set of knowledge, skills, abilities and practical experience of conscious handling of emotional information and volitional regulation of emotional behavior in the process of working with the choir. The components of emotional competence are: personal and cognitive component (ability to cognitive activity in the field of emotional information), analytical and interpretive component (ability to analyze and interpret emotional information), sensory and expressive component (ability to create emotional-resonant musical space by means of conducting expression) and reflexive and regulatory component (ability to control and timely regulation of emotional resonance).

Key words: emotions, competence, emotional competence, choir training, future teachers of music art, component structure of emotional competence.
Постановка проблеми у загальному вигляді. Швидкоплинні зміни у соціокультурному просторі України вимагають від представників соціономічних профресій значного оновлення їхнього професійного профрілю. Фахові вміння і навички педагогічних працівників мають бути, безумовно, на високому рівні, але профресійна діяльність вчителя вимагає значної розвиненості соціальної, емоційної та комунікативної компетентності, як така, що здійснюється в системі «людина-людина». Виконання професійних фрункцій має доповнюватися здатністю до ефективної комунікації, вміннями діяти в консрліктних і стресових ситуаціях, запо- бігати профресійному самовигоранню, бути для здобувачів освіти тьютором, коучем, успішним фахівцем, який надихає, здійснює емоційну підтримку. Особливо високого значення це набуває в контексті діяльності вчителя музичного мистецтва, яка здійснюється на основі багатовекторної та емоційно насиченої художньої комунікації. Така діяльність вимагає від учителів здатності залучити учнів до свідомого, емоційного і вмотивованого осягнення творів мистецтва. Відповідно, вчитель музичного мистецтва не може бути емоційно пасивним. Усі аспекти музично-педагогічної діяльності потребують від фрахівців значної емоційної 
регуляції - як власного емоційного стану, так і емоційного сприймання і емоційної поведінки учнів. Усвідомлене і успішне сприймання, інтерпретація та трансляція емоційної інфрормації $€$ важливою складовою профресійної компетентності майбутніх учителів музичного мистецтва.

Дослідження емоційної складової в контексті хормейстерської діяльності майбутніх учителів музичного мистецтва також має надзвичайно високу актуальність. Майбутні хормейстери мають опанувати здатність транслювати емоційно-образний зміст музичного твору виконавцям хору в режимі протягом його виконання жестом, мімікою, здійснювати емоційно-вольовий вплив для об'єднання всіх виконавців одним художньо-емоційним станом. 3 огляду на це, наукова проблема емоційної компетентності майбутніх учителів музичного мистецтва в процесі хормейстерської підготовки вимагає ґрунтовного і ретельного вивчення як така, вирішення якої сприятиме підвищенню ефективності їхньої фрахової підготовки.

Аналіз останніх досліджень і публікацій. У контексті обраної теми дослідження актуальними $є$ наукові роботи педагогів, психологів і музикантів, які вивчали різні аспекти емоційної компетентності. Результати вивчення емоційності, емоційної культури, емоційного інтелекту, емоційної зрілості та емоційної компетентності як чиннику успішності, ефективності, профресіоналізму, самореалізації висвітлені в роботах психологів І. Андрєєвої [1], Д. Гоулмана [2], Дж. Мейєра [12], М. Рейнолдса [8], О. Саннікової [10] та інших науковців. Вітчизняні сучасні дослідники в галузі педагогіки і психології вивчали емоційну компетентність у контексті забезпечення психологічного здоров'я. Емоційна компетентність визначається як важливий чинник «у досягненні успіху в житті людини та відчутті щастя, як шлях до гармонійного функціонування особистості» [5]. О. Льошенко здійснює вивчення емоційної компетентності на основі порівняльного аналізу та визначення кореляції з соціальним інтелектом. Авторка зазначає, що емоційна компетентність це «перетворення та прогресивний розвиток емоційної сфери суб'єкта 3 метою самовдосконалення, самореалізації, становлення суб'єкту зрілою особистістю, яка творить себе та сприяє творенню інших» [4, с. 161]. Різні аспекти розвитку емоційної сфрери особистості досліджуються як чинники підвищення ефективності діяльності вчителя музичного мистецтва. В якості однієї 3 необхідних складових професійної компетентності майбутніх учителів музичного мистецтва О. Просіна визначає емоційний інтелект [7]. Слушною є думка С. Крамської, яка підкреслює, що емоційна культура вчителя музичного мистецтва $€$ передумовою успішного здійснення фрахової діяльності [3, с. 257].
Виділення не вирішених раніше частин загальної проблеми. Досить висока актуальність зазначеної проблематики та певний брак розробленості феномену емоційної компетентності майбутніх учителів музичного мистецтва, зокрема в контексті хормейстерської підготовки, зумовлює визначення теми і мети статті.

Мета статті полягає в обґрунтуванні сутності, змісту і компонентної структури емоційної компетентності майбутніх учителів музичного мистецтва в контексті хормейстерської підготовки.

Виклад основного матеріалу. Компетентнісний підхід до освітнього процесу є таким, що відповідає динамічним процесам концептуальних змін у суспільстві. Ідеї цього підходу порушують обмеження знаннєвоорієнтованої парадигми освітнього простору, спрямовуючи методи і технології викладання до траєкторій творчого пошуку. У контексті компетентнісного підходу освіта орієнтується не на трансляцію і запам'ятовування інформації, а на опанування здатності до прийняття варіативних і конструктивних рішень. Основною рисою компетентності можна визначити усвідомленість ставлення до діяльності, яка перетворює професійний досвід на інтегральну особистісну характеристику.

Діяльність вчителя музичного мистецтва передбачає одночасне вирішення непередбачуваних різноаспектних (мистецьких, педагогічних, психологічних, комунікативних та інших) проблем. Вказується, що професійна компетентність вчителя музичного мистецтва перетинається 3 його світоглядом та є чинником фрахової самореалізації [9].

Емоційна компетентність вивчається вченими як складне інтегральне утворення. І. Матійків визначає емоційну компетентність як «готовність і здатність людини гнучко управляти емоційними реакціями, як власними, так і інших людей, адекватно до ситуацій і умов, що змінюються» [6, с. 145]. Крім того, автор додає, що емоційна компетентність особистості має у підґрунті світоглядну позицію як сукупність ціннісних орієнтацій і настанов, ставлення до дійсності - до соціуму і до власної особистості [6, с. 150].

Емоційну компетентність доцільно тлумачити як чинник забезпечення ефективної комунікації фрахівця. Також вона має певний перетин з френоменом емоційного інтелекту, який уможливлює інтелектуальне осягнення емоцій та чуттєве сприйняття інтелектуальної інформації. Це підтверджується в дослідженні І. Андрєєвої, де вказується, що емоційна компетентність - це «сукупність знань, умінь і навиків, що дозволяють приймати адекватні рішення й діяти на основі результатів інтелектуальної обробки зовнішньої і внутрішньої емоційної інфрормації» [1, с. 85].

Емоційна компетентність відіграє значну роль в аутокомунікації особистості як здатності налагоджувати зв'язок із власним внутрішнім світом, 
усвідомлювати власні думки, емоції, почуття, рефлексувати власне мислення і поведінку. На основі емоційної компетентності особистість відкривається власним емоційним переживанням і набуває здатності регулювати власну емоційну поведінку. Це $€$ запорукою гармонізації психоемоційного стану особистості, особливо у стресових умовах публічних виступів. В умовах браку емоційної компетентності фрахівець під час виконання музичного твору або під час організації художньої комунікації з учнями втрачає щирість і, швидше за все, відіграє роль, а не передає живі почуття, що значно зменшує позитивний виховний емоційний вплив через мистецтво на інших.

Розвинена і усвідомлена емоційна сорера особистості $€$ важливою складовою хормейстерської майстерності, яка уможливлює успішний музично-виконавський процес у хорі. На основі узагальнення теоретичних і методичних положень ґрунтовних робіт, присвячених диригентсько-хормейстерській підготовці, 3. Софрроній зазначає, що для здійснення професійної хормейстерської діяльності майбутнім учителям музичного мистецтва ще у процесі навчання необхідно оволодіти «емоційно-психологічним впливом на хоровий колектив, що є важливим складником хормейстерських умінь і навичок» [11, с.251]. Емоційно-творча складова профресійної комунікації хормейстера здатна забезпечити психологічний комфорт і духовну єдність диригента зі всіма учасниками хорового колективу. Емоційна взаємодія в хоровому колективі відбувається постійно.

На тлі таких міркувань доцільно обґрунтувати особистісно-професійний конструкт «емоційна компетентність майбутніх учителів музичного мистецтва в контексті хормейстерської підготовки» як інтегральну якість, комплекс знань, умінь, навичок і практичного досвіду усвідомленого оперування емоційною інформацією та вольової регуляції емоційної поведінки в процесі роботи з хором із метою оптимізації емоційного аспекту художньої комунікації з учасниками хорового колективу через рефрлексивність, емпатію та доцільну диригентську експресію. Структура емоційної компетентності передбачає виокремлення чотирьох компонентів, кожен з яких реалізує певні компетенції.

Перший компонент визначається як «особистісно-пізнавальний». Виокремлення такого компоненту зумовлюється тим, що майбутні учителів музичного мистецтва - хормейстери мають володіти здатністю до активної, самостійної та особистісно вмотивованої пізнавальної діяльності. У контексті емоційної компетентності особистісно-пізнавальний компонент відповідає за усвідомлене та цілеспрямоване пізнання майбутніми фахівцями власних емоцій та їхнього впливу на хормейстерську діяльність, емоцій, закладених композиторами в музичний текст, емоцій інших людей - членів хорового колективу. Така складна пізнавальна діяльність спирається на мотивацію, тобто на особистісну потребу в оптимізації емоційної взаємодії, яка, у свою чергу, ґрунтується на розумінні емоційної інфрормації як професійної та особистісної цінності. Особистісно-пізнавальний компонент забезпечує фрункціонування всіх інших складових емоційної компетентності. Він $€$ каталізатором виникнення інтересу до емоційної інфрормації, який мобілізує механізми пізнання.

Аналітико-інтерпретаційний компонент емоційної компетентності майбутніх учителів музичного мистецтва в контексті хормейстерської підготовки забезпечує здатність до ретельного, ґрунтовного і об'єктивного аналізу та інтерпретації емоційної інфрормації у двох напрямках:

1) міжособистісний - реалізується у взаємодії хормейстера з учасниками хорового колективу та уможливлює ефективне тлумачення зворотного емоційного зв'язку від виконавців і через нього оцінку ефрективності власного експресивно-емоційного впливу на виконавців;

2) мистецький - реалізується у роботі над музичним текстом, яка передбачає осягнення емоційно-образного наповнення музичного твору, тлумачення семантичного виразу смислового повідомлення автора, вироблення власної виконавської концепції музичного твору та планування роботи щодо її реалізації.

Виокремлення чуттєво-експресивного компоненту емоційної компетентності майбутніх хормейстерів зумовлюється тим, що весь спектр емоцій та почуттів, закладених у музичний твір, диригент може передати хору в процесі виконання засобами диригентської експресії. До таких засобів відносяться диригентський жест, пантоміміка, погляд диригента-хормейстера. Усі вказані елементи в комплексі дозволяють не лише досягти бажаного звучання, інтонування, але й викликати у виконавців необхідний емоційний відгук, завдяки якому буде втілений емоційно-образний зміст музичного твору. Для фрормування емоційного відгуку хормейстер, перш за все, має згенерувати у собі певний відповідний емоційний стан, який у результаті вольового зусилля буде транслюватися хору, внаслідок чого виникне необхідний художньо-емоційний резонанс між хормейстером, хором і слухачами. Цей компонент дозволяє обирати найдоцільніші засоби диригентської експресії, конгруентно і щиро реалізувати емоційний посил, а також створювати у процесі виконання музичного твору емоційно-резонансний музичний простір.

Останній компонент емоційної компетентності майбутніх учителів музичного мистецтва - рефрлексивно-регулятивний. Рефлексивні механізми уможливлюють здатність особистості до критичної оцінки власних дій з метою їх оптимізації. У контексті емоційної компетентності рефрлексивно-регу- 
лятивний компонент відповідає за відстеження, спостереження і оцінку власних емоцій і дій щодо доцільної їх трансляції в процесі роботи з хоровим колективом. Така критична оцінка зумовлює активізацію регулятивних механізмів, які забезпечують швидке і ефективне виправлення звучання хору через регуляцію власних емоцій та емоцій учасників хорового колективу. Рефрлексивно-регулятивний компонент емоційної компетентності майбутніх учителів музичного мистецтва - це передумова профресійного зростання індивіду, чинник спрямування особистості на власний розвиток та профресійне самовдосконалення.

Висновки. Отже, емоційна компетентність майбутніх учителів музичного мистецтва $€$ важливою складовою фахового становлення в контексті хормейстерської підготовки. Емоційна компетентність майбутніх учителів музичного мистецтва в контексті хормейстерської підготовки визначається як інтегральна якість, комплекс знань, умінь, навичок і практичного досвіду усвідомленого оперування емоційною інформацією та вольової регуляції емоційної поведінки в процесі роботи 3 хором. Складовими емоційної компетентності визначено особистісно-пізнавальний, аналітикоінтерпретаційний, чуттєво-експресивний та реолексивно-регулятивний компоненти. На наступному етапі дослідження означеної проблематики доцільно обґрунтувати методологічні засади фрормування емоційної компетентності в майбутніх учителів музичного мистецтва у процесі хормейстерської підготовки.

\section{БІБЛІОГРАФІЧНИЙ СПИСОК:}

1. Андреева И. Азбука эмоционального интеллекта. Санкт-Петербург : «БХВ-Петербург», 2012. $288 \mathrm{c}$.
2. Гоулман Д. Эмоциональный интеллект. Москва : ACT, 2008. 478 c.

3. Крамська С. Методичні аспекти формування емоційної культури майбутнього вчителя музичного мистецтва. Педагогічні науки: теорія, історія, інноваційні технології. 2015. №5. С. 255-265.

4. Льошенко О. Соціальна та емоційна компетентність: порівняльний аналіз. Актуальні проблеми соціології, психології, педагогіки. 2012. Вип. 16. C. 157-162.

5. Любіна Л. Емоційна компетентність як показник психологічного здоров'я особистості майбутніх лікарів. Психологічний часопис. 2018. № 5. С. 81-97.

6. Матійків І. Емоційна компетентність як психологічний об'єкт виховання особистості майбутнього фрахівця професій типу «людина - людина». Педагогіка і психологія профресійної освіти. 2013. № 2. C. 144-153.

7. Просіна О. Розвиток емоційного інтелекту як основа формування професійної компетентності майбутніх учителів музики. Гірська школа Українських Карпат. 2018. № 18.

8. Рейнолдс М. Коучинг: эмоциональная компетентность: Направьте свои эмоции (EQ) на успех в работе. Москва: Центр поддержки корпоративного управления и бизнеса, 2003. 103 с.

9. Савченко Р. Поетапна методика фрормування музично-педагогічної компетентності майбутніх педагогів дошкільної освіти : матер. Міжн. конференції «Україна - ЄС. Сучасні технології, економіка та право». Київ, 2017. С. 27-31.

10. Саннікова О. Континуально-ієрархічна модель емоційності. Наука і освіта. 2014. № 1. С. 44-50.

11. Софрроній 3., Чурікова-Кушнір О. Методичні засади хормейстерської підготовки майбутніх учителів музичного мистецтва. Духовність особистості: методологія, теорія і практика. 2020. № 97. C. 245-258.

12. Mayer, J. D. A field guide to emotional intelligence. Emotional intelligence in everyday life. Philadelphia, P. A.: Psychology Press, 2001. pp. 3-24. 